\begin{tabular}{|c|c|c|}
\hline Beitr. Ent. & Keltern & ISSN 0005 - 805X \\
\hline $\mathbf{5 4}(2004) 1$ & S. $127-146$ & 28.05 .2004 \\
\hline
\end{tabular}

\title{
New records of Coleophoridae from Romania
}

\section{(Lepidoptera)}

\section{GIORGIO BALDIZZONE (*), ZDENKO TOKÁR, ZOLTÁN KOVÁCS, SÁNDOR KOVÁCS}

With 2 figure plates

\section{Summary}

New records of Romanian Coleophoridae are reported, based on the collections of S. KOVÁCS and Z. KOVÁCS. Twenty-two coleophorids are recorded from Romania for the first time. Coleopbora balcanica BALDIZZONE, 1994 syn. n. is regarded as a junior synonym of C. coarctataephaga Toll, 1961. Geographical and biological information on all the species is provided.

\section{Key words}

Lepidoptera, Coleophoridae, Romania, new records, new synonymy

\section{Zusammenfassung}

Basierend auf der Sammlung von S. und Z. KovÁCS, werden neue Funde von rumänischen Coleophoridae gemeldet. Als Neufunde für Rumänien konnten 22 Arten festgestellt werden. Coleopbora balcanica BALDIZZONE, 1994 wird als neues Synonym von C. coarctataephaga TOLL, 1961 erkannt. Für alle Arten werden geographische und biologische Informationen gegeben.

This paper is based on abundant material of Coleophoridae collected in Romania by brothers SÁNDOR and ZOLTÁN KOVÁCS during a rather long period of the years 1973-2001. Two first authors were able to examine an important part of the material. Among many interesting coleophorids they could recognize twenty-two species that have not yet been recorded from the country.

In the second part of our paper we summarize information on another fifty-two new records of Coleophoridae from Romania reported by other authors. These new records were not included in the Checklist of European Coleophoridae (BALDIZZONE 1996a) or in its addition (BALDIZZONE \& VAN DER WOLF 2000). We have found sixteen of species listed in the second part also among examined material of the collections of S. \& Z. KOVÁCS, enabling us to confirm these species from Romania.

Both the 1996 checklist and its 2000 update comprise 104 species known from Romania. Our article provides information on further 74 species. Consequently, the number of species of Romanian Coleophoridae is now 178.

(*) Contribution to the knowledge of Coleophoridae. CIII 
All specimens listed below are deposited in the collections of S. KOVÁCS \& Z. KOVÁCS in Sf. Gheorghe or Miercurea Ciuc, Romania and partly also in the collection of Z. TOKÁR in Michalovce, Slovakia.

The numbers in square brackets behind each species name are taken over from the mentioned above European checklists.

1. Records of Coleophoridae new to Romania collected by S. \& Z. KOVÁCS (additions to the Checklist of European Coleophoridae)

\section{Coleophora alnifoliae BARASCH, 1934 [2461]}

Carpații Orientali, Tușnadul Nou, Valea Mijlocie, $600 \mathrm{~m}$, 17.VI.2000, $10^{\star}$, 1 \% ; Munții Ciucului, Şumuleul Mare, 700 m, 8.VI.2000, 1 \% ; Munţii Harghita, Hargitaliget, 700 m, 10.VII.2001, 1 우 (det. Z. TOKÁR)

Geographical distribution: Almost all Europe except the southernmost zone, North America (Canada).

Biology: The host plants are Alnus glutinosa (L.) GAERTN., Alnus incana (L.) MOENCH., Betula spp. (Betulaceae). Larvae feed from VIII-IX and after hibernation up to VI. Adults occur in VI-VIII (HERING 1957, REIPRICH 2001).

\section{C. vacciniella HERRICH-SCHÄFFER, 1861 [2481]}

Carpaţii Orientali, Munţii Harghita, 1100 m, Tinovul Lúcs, 11.VI.1993, 1 o (det. Z. TOKÁR) Geographical distribution: Boreomontane European species. It ranges from the arctic regions towards Alps and Central European mountains.

Biology: Various food plants for C. vaciniella were recorded: Vaccinium myrtillus L., V. vitisidaea L., V. uliginosum L. (Vacciniaceae), Betula pendula ROTH, B. pubescens EHRH., B. nana L. (Betulaceae), Myrica gale L. (Myricaceae), Rubus chamaemorus L. (Rosaceae), Salix lapponum L. (Salicaceae), Chamaedapbne calyculata (L.) MOENCH, Andromeda polifolia L. (Ericaceae). Young larvae in mines, later feed leaves above, from V-VI to IV. Adults emerge from V to VII (HERING 1957, ITÄMIES \& TABELL 1991, 1997, TOLL 1953).

\section{C. plumbella KANERVA, 1941 [2483]}

Carpații Orientali, Munții Harghita, 1100 m, Tinovul Lúcs, 11.VI.1998, 1 đ (det. Z. TOKÁR); the same data, 2 o 9 (det. Z. KOVÁCS)

Geographical distribution: From Fennoscandia and Denmark eastwards to Russian Karelia, southwards to Poland and Ukraine.

Biology: Larvae on Vaccinium uliginosum L. (Vacciniaceae) and Rubus chamaemorus L. (Rosaceae) from IX-X to IV. Adults in V-VII (ITÄMIES \& al 1979, TOLL 1953). The specimens were collected in a peat bog (as well as C. vacciniella H.-S. and C. vitisella GREGS.) where Vaccinium uliginosum L. does not occur, but Vacinium myrtillus. L. and V. vitis-idaea L. are abundant. 


\section{C. vitisella GREGSON, 1856 [2484]}

Carpații Orientali, Munții Harghita, $1100 \mathrm{~m}$, Tinovul Lúcs, 11.VI.1998, $1 \sigma^{\star}$ (det. Z. TOKÁR); the same locality and date, 3 q $q$ (det. Z. KOVÁCS)

Geographical distribution: Widely distributed in north, western, northeastern and central Europe. The southernmost European localities are in the Italian Alps and the Carpathians. Biology: Larvae feed on Vaccinium vitis-idaea L. (Vacciniaceae) or Pyrola L. (Pyrolaceae). They hibernate probably twice (TOLL 1953). Adults in IV-VI.

\section{C. klimeschiella TOLL, 1952 [2530]}

Dobrogea, Grindul Chituc, Vadu (itoral), 28.VII.2000, $1 \sigma^{*}$ (det. G. BALDIZZONE)

Geographical distribution: Coleophora klimescbiella originates from Central Asia and Asia Minor, its description, however, was based on material from Hungary. In Europe it is known also from Russia and Greece. During previous decades the species was widely established in USA in Utah and New Mexico (pers. com. H.W. VAN DER WOLF) in California and Texas where it seriously infests the host plants (VILLEGAS \& HARRIS 2002).

Biology: Larvae live on Salsola spp. (Chenopodiaceae). Our specimen was collected at the Black Sea coast in saltmarshes.

\section{C. medelichensis KRONE, 1908 [2553]}

Carpați Orientali, Praid (jud. Harghita), Muntele de Sare, 18.VIII.2000, $1 \sigma^{\star}$ (det. Z. TOKÁR) Geographical distribution: Southern Europe from Spain to the Balkans and Crete, southern parts of central Europe, Asia Minor (BALDIZZONE 1981, 1996a).

Biology: Host plants are Doryonium spp. (Fabaceae). Cases can be found from VI to X and after a diapause up to V-VI (GREGOR \& al 1986, SZÖCS 1977). Imagoes have been collected in IV-VIII. The specimen was collected among flats of saline vegetation.

\section{C. rectilineella FISCHER V. RÖSLERSTAMM, 1843 [2579]}

[Transylvania], Glodeni (jud. Mureş), 10-11.V.1985,10 (det. Z. TOKÁR)

Geographical distribution: Coleophora rectilineella has been recorded from scattered localities in France, northern Italy and central Europe.

Biology: The species is polyphagous. Larvae feed from VIII and after overwintering to IV.VI on species of Primula L. (Primulaceae), Salix L. (Salicaceae), Alchemilla L. (Rosaceae), Anthyllis L. (Fabaceae), Acosta ADANS., Aster L., Cbrysanthemum L., Leucanthemum MiLl., Lencantbemopsis alpina (L.) HEYWOOD (Asteraceae), Cerastium L. (Caryophyllaceae), Globularia cordifolia L. (Globulariaceae), Ranunculus acris L. (Ranunculaceae) (BALDIZZONE 1996b, KLIMESCH 1939, 1990). Adults occur in V-VIII.

Phylogenetics: Externally the species is very similar to $C$. fringillella ZELLER, 1839. The forewing basal colour of $C$. rectilineella is somewhat darker than in $C$. fringillella and therefore white margins seem more contrast in the former species (TOLL 1953). 


\section{C. dignella TOLL, 1961 [2613]}

Câmpia Transilvaniei, Viişoara (Câmpia Turzii), 27.V.2000, $10^{\star}$ (det. Z. TOKÁR); same locality, 1.VI.1996, 1 \% ; Dobrogea, Lespezi, 18.V.1994, 1 \% (det. Z. KoVÁCS)

Geographical distribution: $C$. dignella is known to occur in the Mediterranean area from Spain to Turkey (BALDIZZONE 1996a, KOÇAK \& SEVEN 2001). It has been also recorded from few localities in central Europe: in Austria, the Czech Republic and only old records are known from Germany (GAEDIKE \& HEINICKE 1999).

Biology: According to KASY (1985) host plants are Onobrycbis arenaria (KIT. ex SCHULT.) DC. and O. viciifolia SCOP. (Fabaceae). Adults have been collected in V-VI. The specimens were collected in steppe habitats on highly isolated hillsides.

\section{C. helichrysiella KRONE, 1909 [2636]}

Dobrogea, Grindul Chituc, Vadu, 28.VII.2000, $1 \sigma^{*}$; Dobrogea, Valea Casimcei, Cheia,

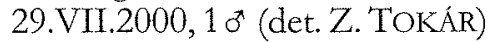

Geographical distribution: Southern Europe from Portugal and Spain through France, Italy, and Dalmatia to the Balkan Peninsula and Crete (BALDIZZONE 1981).

Biology: Larvae feed on Helicbrysum italicum (ROTH) GUSS (Asteraceae). Imagoes live from V to VIII.

\section{C. alticolella ZELLER, 1849 [2692]}

Carpații Orientali, Munții Harghita, Piricske, 900 m, 1.VII.2000, $10^{\text {* }} 1$ 1 ; Transylvania, Mestecănişul de la Reci, 540 m, 12.VII.1991, 1 \% (det. Z. TOKÁR)

Geographical distribution: Almost all Europe, southwestern Asia (Iran), northern Africa (Tunisia) and USA (BALDIZZONE 1994, 1997).

Biology: Larvae can be found in summer and autumn and after a diapause in early spring on Juncus spp. (Juncaceae). SCHÜTZE (1931) mentions also Luzula DC. Juncaceae) and Scirpus L. (Cyperaceae) as host plants. Adult moths have been collected from III (in south) to VIII.

\section{C. taygeti BALDIZZONE, 1983 [2698]}

Munții Bucegi, 1600 m, Vânturiș, 21.VI.1993, $10^{*}$ (det. Z. TOKÁR); the same data, 1 specimen without abdomen (det. Z. KovÁcs)

Geographical distribution: The species has been known only from Spain, Italy, France, [VAN DER WOLF 2001], Greece (BALDIZZONE 1996a) and Turkey (KOÇAK \& SEVEN 2001) up to now.

Biology: Host plant and life history are unknown. Moths were collected in VI-VII.

\section{C. linosyris M. HERING, 1937 [2715]}

Câmpia Transilvaniei, Lechinţa (jud. Mureş), 31.VIII.1996, 1 ơ (det. Z. TOKÁR) 
Geographical distribution: Central Europe extending to France and northern Italy in scattered localities.

Biology: Larvae feed on Crinitina linosyris (L.) SOJÁK (Asteraceae). Adults have been collected in VIII-XI. This species, as well as the following one were collected on hillsides covered with authentic steppe vegetation where their host plant is very abundant.

\section{C. pseudolinosyris KASY, 1979 [2719]}

Câmpia Transilvaniei, Viiş̧oara (Câmpia Turzii), 11.IX.1998, 1 đo (det. G. BALdizzonE)

Geographical distribution: From northern Italy through central Europe, Balkans and southern European Russia, Kazakhstan up to the Bajkal area (ANIKIN \& FALKOVITSH 1997, BALDIZZONE 1996a, FALKOVITSH \& al 1997).

Biology: Larvae on leaves and seeds of Crinitina linosyris (L.) SOJÁK, Tripolium pannonicum (JACQ.) DOBROCZ. (MAREK \& GREGOR 1989) and Aster punctatus WALDST. \& KIT. (Asteraceae) (KASY 1979) from IX-XI to VI. Adults fly in VII-IX.

\section{C. atriplicis MEYRICK, 1928 [2737]}

\section{Dobrogea, Cetatea Histria, 25-26.VIII.1999, 1 우 (det. G. BALDIZZONE)}

Geographical distribution: The species has been reported from a large part of western and northern Europe from Great Britain and France across Fennoscandia to the Baltic States and northwestern Russia. In central Europe it is only known from widely scattered localities in Germany, Poland and Hungary.

Biology: C. atriplicis larvae feed on seeds of species of Atriplex L. (SVENSSON 1993), Chenopodium L. (IVINSKIS \& SAVENKOV 1991) and Suaeda FORSK. (Chenopodiaceae) from VIII-IX with hibernation to V. Adults occur mostly in VII-VIII. A vast saltmarsh near the Black Sea coast is the habitat of the Romanian population.

\section{C. pappiferella O. HoFMANN, 1869 [2738]}

Carpaţii Orientali, Munții Harghita, Cekend, 800 m, 20.V.1999, 1 9 (det. Z. TOKÁR)

Geographical distribution: C.pappiferella has a wide distribution in notthern and central Europe. In the Italian Alps it has been collected up to altitudes of about $2800 \mathrm{~m}$ (BALDIZZONE 2000).

Biology: Larvae feed on seeds of Filago L. (SCHÜTZE 1931), Antennaria GAERTN. (HRUBÝ 1964) and Gnaphalium L. (Asteraceae) (PATZAK 1974) from VII. They occasionally hibernate twice. Adult moths emerge from V to VII.

\section{C. deviella ZELLER, 1847 [2751]}

Dobrogea, Cetatea Histria, 11.VIII.2001, 1 우 (det. Z. TOKÁR)

Geographical distribution: The distribution of the species ranges in northwestern Europe from Great Britain through Holland and Germany to Denmark, widely in the Mediterranean area (Spain, Sardinia, Sicily, Tunisia, Greece), the Balkan Peninsula 
(BALDIZZONE 1996a, BALDIZZONE \& TRIBERTI 1982). Recently it has been recorded also from southeastern European Russia (ANIKIN \& FALKOVITSH 1997).

Biology: $C$. deviella larvae feed on leaves and seeds of Suada FORSK. and Bassia ALL. (=Kochia) (Chenopodiaceae) from VII and after hibernation to V. A period of occurrence of adults is relatively long from V to IX. The recorded specimen was collected in the same marshy locality as $C$. atriplicis.

\section{C. odorariella MÜHLIG, 1857 [2761]}

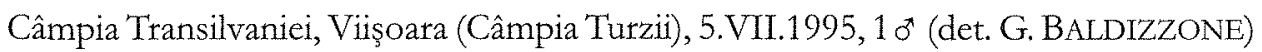

Geographical distribution: $C$. odorariella occurs from southwestern to southern parts of central Europe.

Biology: The host plants of larvae of C. odorariella are species of Jurinea CASS. and Serratula tinctoria L. (Asteraceae) (SZÖCS 1977). Both plants are abundant on a hillside where our specimen was collected. Larvae feed on leaves from VII-IX and after hibernation up to VI. Adults can be found in VI and VII.

\section{C. scabrida TOLL, 1959 [2775]}

Dobrogea, Munții Măcin, Culmea Pricopanului, 150 m, 27-28.V.1994, $10^{\star}$ (det. Z. TOKÁR); Dobrogea, Bâneasa, Rezervația Canaraua Fetii, 17.V.1994, 1 ㅇ (det. G. BALDIZZONE)

Geographical distribution: The species is widely distributed but local in Europe: Portugal, Spain, France, northern Italy, Macedonia, Germany, Austria, Poland, Sweden, the Baltic States and now also Romania.

Biology: A host plant of the species is Herniaria glabra L. (Caryophyllaceae). Adults have been collected from IV (in southern Europe) to VI.

Phylogenetics: According to RAZOWSKI (1990) C. scabrida polonica TOLL, 1959, a geographical form described from the Carpathian mountain ranges, is not different from the nominal form.

\section{C. amellivora BALDIZZONE, 1979 [2791]}

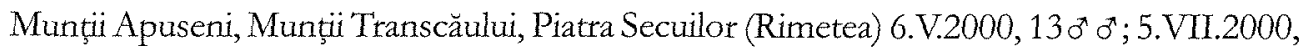
$3 \sigma^{*}$ (det. Z. TOKÁR and Z. KOVÁCS)

Geographical distribution: C. amellivora is widely distributed in Europe from France and northern Italy throughout central to northern Europe (Sweden, Finland, the Baltic States) and Russia.

Biology: The host plants of the species are Aster amellus L., $A$. alpinus L., and $A$. salignus WILLD. (GREGOR \& al. 1984, SCHÜTZE 1931) and according PATZAK (1974) also Solidago spp. (Asteraceae). Larvae feed on leaves from VIII-X and after hibernation to V. Moths occur from IV (in the south) to VIII. 


\section{C. linosyridella FUCHs, 1880 [2801]}

Câmpia Transilvaniei, Viişoara (Câmpia Turzii), 23.IV.1998, $1 \sigma^{\star}$ (det. Z. TOKÁR)

Geographical distribution: The Palaearctic species has a widely scattered distribution in Europe from Great Britain across central Europe to northern Italy and Croatia. It has been recorded also from Japan (VIVES MORENO 1988).

Biology: Larvae feed on leaves of Crinitina linosyris (L.) SOJÁK (Asteraceae) from VIIVIII with hibernation to IV-V (SZÖCS 1977). Adults emerge in IV-VIII.

\section{C. tyrthaenica AMSEL, 1952 [2836]}

\section{Dobrogea, Valea Casimcei, Cheia, 29.VII.2000, 1 q (det. Z. TOKÁR)}

Geographical distribution: The species was described after specimens from Sardinia. Later C. tyrrbaenica has been recorded from northern Italy, Dalmatia, Macedonia, Bulgaria, Greece, Hungary and Russia (the Lower Volga region) (BAIDIZZONE \& HARTIG 1978, ANIKIN \& FALKOVITSH 1997).

Biology: Host plant and early stages are unknown. Adults fly in VII-VIII.

$$
\begin{aligned}
& \text { C. coarctataephaga ToLL, } 1961 \text { [2785] } \\
& \text { (= balcanica BALDIZZONE, } 1994 \text { syn. n.) }
\end{aligned}
$$

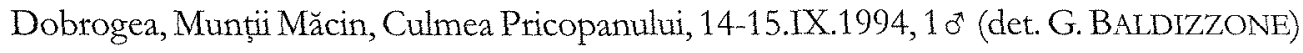
Geographical distribution: C. coartataephaga is known from Macedonia, Albania, northern Greece, Bulgaria, southeastern Romania and Armenia.

Biology: Larvae of the species was found on Acbillea coarctata Polr. (Asteraceae) in V (KLIMESCH 1968). Adult moths were collected from VI to IX.

Remarks: During the preparation of this paper we received information from Mr JUKKA TABELL who concluded that Coleophora balcanica BALDIZZONE, 1994 is a junior synonym of $C$. coartataephaga TOLL, 1961. The latter species was described after material from Macedonia and up till now it is one of least-known European coleophoriids. GLASER (1975) illustrated male genitalia of the species, however, this illustration appeared to be a mistake.

GLASER's drawing (fig. 1) probably represents the genitalia of C. odorariella MÜHLIG \& FREY, 1857. The first author is convinced, after studying material from the KLIMESCH collection in the München Museum, that the true male of C. coarctataephaga is not the one illustrated by GLASER, but the one known by the name of $C$. balcanica.

Photographs are given for the male (fig. 2) and female (fig. 3) genitalia. 


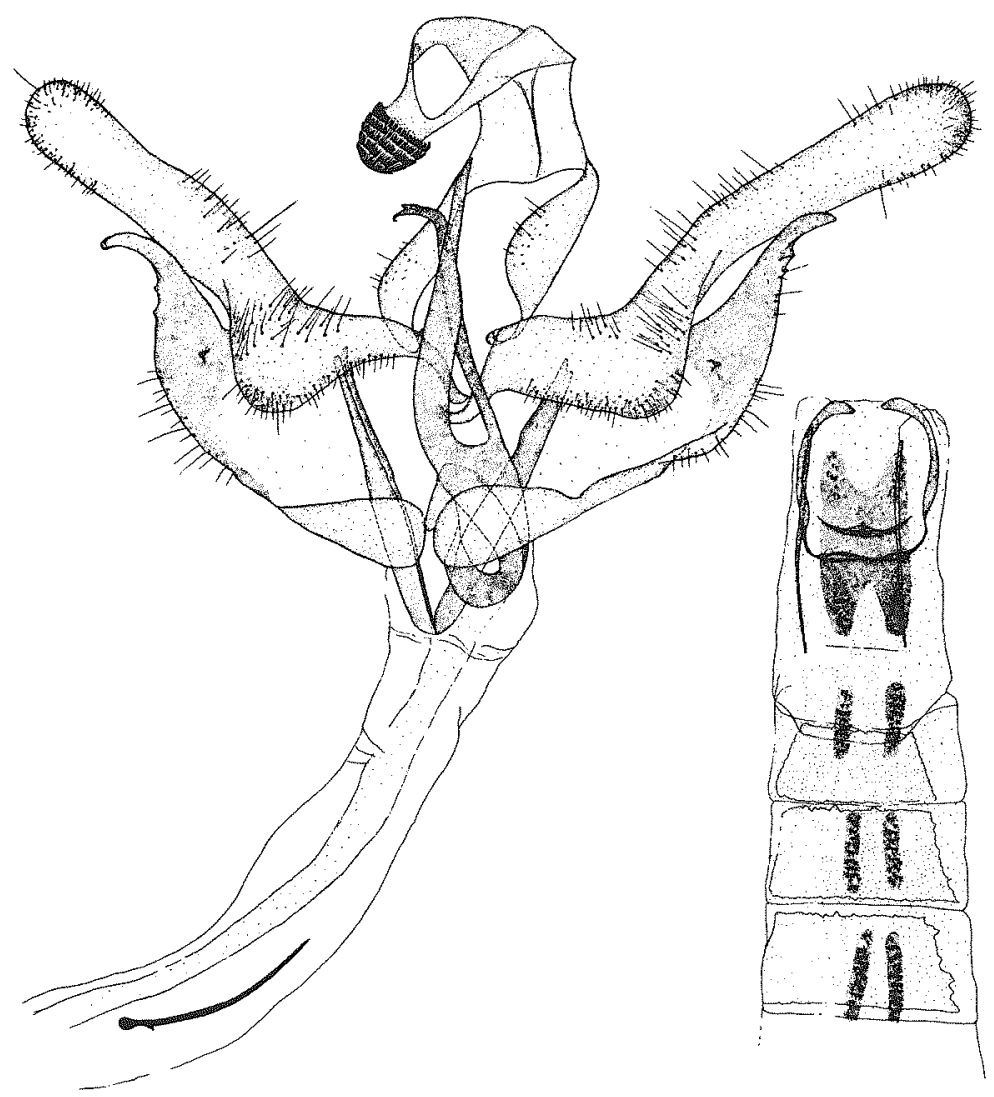

Fig. 1 - Coleophora "coarctataephaga" sensu GLASER, 1975 - GLASER's original drawing.

2. A review of Coleophoridae new to Romania reported by other authors (next additions to the Checklist of European Coleophoridae)

C. spinella (SCHRANK, 1802) [2469]

VICOL (in litt.) recently found the species in Transylvania (Sânmarghita, jud. Mureş).

C. hydrolapathella M. HERING, 1924 [2472]

Reported from Moldova: Pădurea Gârboavele (jud. Galați) (NEMEș \& OLARU 1969, OLARU \& NEMEŞ 1970).

\section{C. trigeminella FUCHs, 1881 [2474]}

Recently recorded from the northwestern part of Romania: Satu Mare (ARDELEAN 1998). 
2
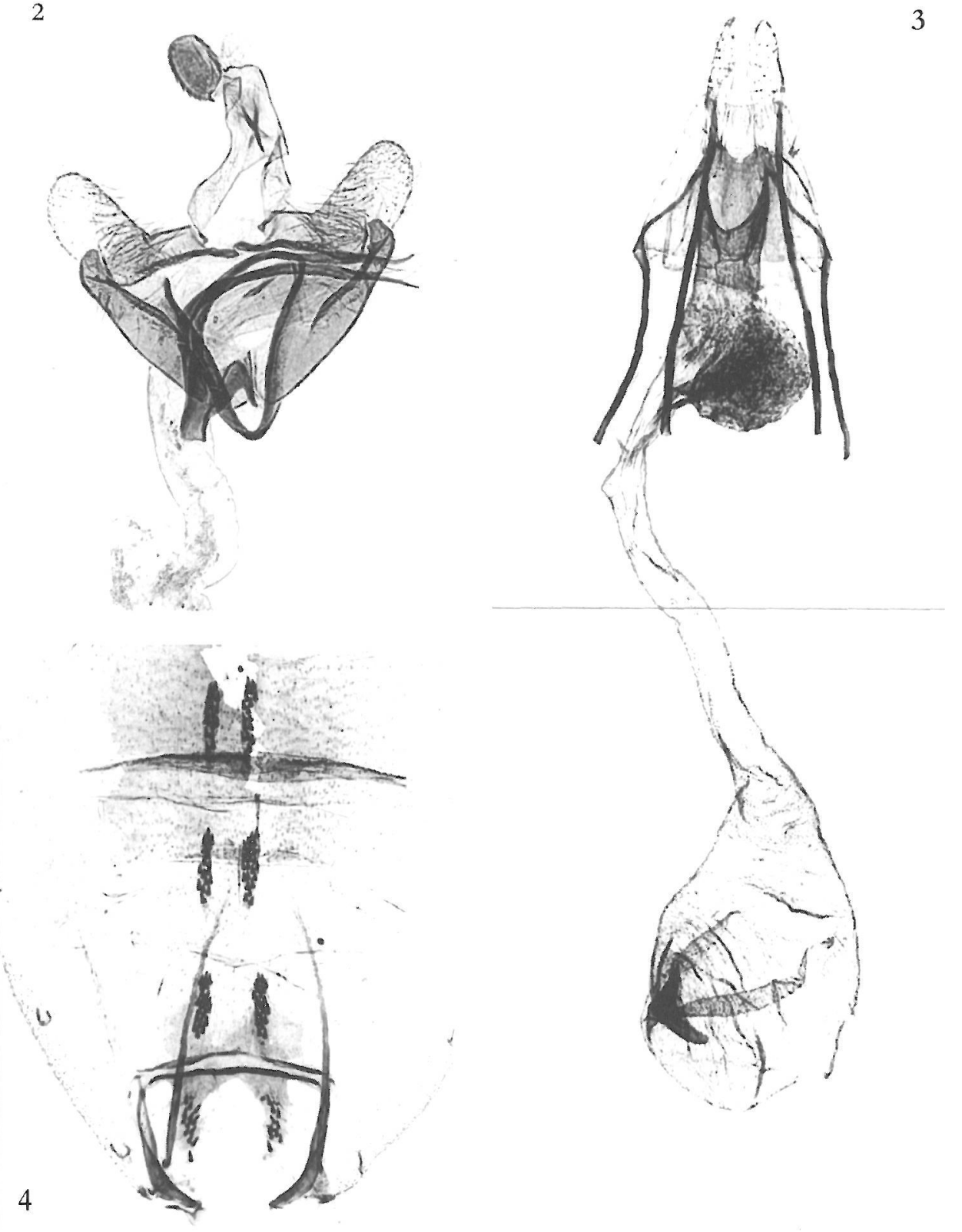

Fig. 2 - C. coartataephaga TOLL - Male genitalia (PG Bldz 12979) "Raupe an Acbillea coarctata, 9.V.1963, Macedonia, Treska Schlucht, ex 1. 9.VI.1963, J. KLIMESCH", coll. BALDizzonE.

Fig. 3 - idem - Female genitalia (PG Bldz 13237) "Raupe an Acbillea coarctata, 9.V.1963, Macedonia, Treska Schlucht, ex 1. 20.VII.1963, J. KLIMESCH”, coll. BALDIZZONE.

Fig. 4 - idem - abdomen. 


\section{C. binderella (KOLLAR, 1832) [2494]}

The species was recorded from a few localities in Moldova: Suceava and Ponoare (NEMEŞ 1968, 1970a) and in the Southern Carpathians: Azuga (Cumpătu) (POPESCU-GORJ 1995).

\section{C. pulmonariella RAGONOT, 1874 [2497]}

Hitherto only an old record from Muntenia has been known (DOBREANU 1937). We found the species in the Eastern Carpathians, Munţii Harghita, Băile Tuşnad, 21.VI.1988, ơ legit: S. KOVÁCS \& Z. KOVÁCS (det. Z. TOKÁR).

\section{C. frischella (LINNAEUs, 1758) [2499]}

The species was placed into the checklist of Romanian Microlepidoptera by POPESCUGORJ (1984). It was mentioned from several Romanian localities: Moldova (CARADJA 1901, Nemeş 1968, NEMEȘ \& DÃNILA 1970), Transylvania (CzEKELIUS 1917), Oltenia (POPESCU-GORJ \& al. 1975), Dobrogea (NEMEș 1968) and Banat (KÖNIG 1975, CĂPUŞE \& KOVÁCS 1987). However, it has not yet been included to the European Checklist (BALDIZZONE 1996a, BALDIZZONE \& VAN DER WOLF 2000) yet because the first authot put into the list only records of $C$. frischella checking by him. Because frequent confusions with the closely related species of $C$. trifolii (CURTIS, 1932) the records from Romania require verification.

\section{C. lineolea (HAWORTH, 1828) [2518]}

The species was reported before from Transylvania: Vâlcele (jud. Covasna) (CZEKELIUS 1908) and Dobrogea: Pădurea Hagieni (POPESCU-GORJ \& DRĂGHIA 1967). We found a further specimen in the Eastern Carpathians, Cheile Bicazului, 8-9.VI.1988, o", legit: S. KOVÁCS \& Z. KOVÁCS (det. Z. TOKÁR).

\section{C. onobrychiella ZELLER, 1849 [2552]}

Only one old record from Romania is known: Transylvania, Tăureni (jud. Mureş) (ROTHSCHILD 1912). The record requires verification.

\section{C. genistae STAINTON, 1857 [2564]}

Recorded from Banat (REBeL 1911) and Transylvania: Sibiu (CZEKELIUS 1933-1934).

\section{C. squamella CONSTANT, 1885 [2571]}

Only mentioned from Moldova: Pădurea Gârboavele (jud. Galati) (OLARU \& NeMES 1970). We found C. squamella in the steppe habitats of the Transylvanian Basin: Toldal (jud. Mureş), 3.V.1986, Câmpia Transilvaniei, Viişoara (Câmpia Turzii), 23.IV.1998, legit: S. KOVÁCS \& Z. KOVÁCS (det. Z. TOKÁR). 


\section{C. bilineatella ZELLER, 1849 [2575]}

The species was collected in Romania only in Transylvania: Vâlcele (jud. Covasna) (CZEKELIUS 1917). We found it also in different transylvanian localities: Câmpia

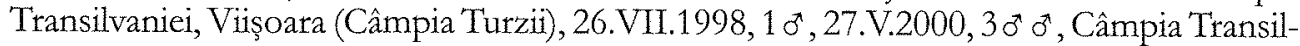
vaniei, Lechința (Mureş), 31.V.1996, Carpații Orientali, Munţii Harghita, 1100 m, Tinovul Lúcs, 11.VI.1993, 10, legit: S. KOVÁCS \& Z. KOVÁCS (det. Z. TOKÁR).

\section{C. deauratella LIENIG \& ZELLER, 1846 [2585]}

The species was included in the Checklist of Romanian Microlepidoptera by POPESCUGORJ (1984) based on several former publications of CARADJA (1901), CZEKELIUS (1917), NEMEŞ (1968) and REBEL (1911).

\section{C. pyrrhulipennella ZELLER, 1839 [2601]}

In Romania known only from Moldova: Agapia, jud. Neamț (NEMEȘ 1974).

\section{C. brevipalpella WOCKE, 1874 [2602]}

Recorded from Transylvania: Sibiu (CZEKELIUS 1917).

\section{C. setratulella HERRICH-SCHÄFFER, 1855 [2603]}

Several records from different parts of Romania exist: Moldova, Lucina (HORMUZAKT 1907), Poiana Stampei (Tinovul Mare) (NEMEŞ \& LuNGOCI 1972), Transylvania, Câmpia Transilvaniei (Tăureni) (ROTHSCHILD 1912) and the Southern Carpathians, Sinaia (POPESCUGORJ 1995).

\section{C. virgatella ZELLER, 1849 [2606]}

The first record of the species was reported from Sibiu (CZEKELIUS 1933-1934). We found it in the Eastern Carpathians, Munții Nemira, Lassúág, 1100 m, 21-22.VI.1996, 1 ; Munţii Baraolt, 650 m, Sf. Gheorghe, 8.VII.1984, 1\%, legit: S. KovÁcS \& Z. KOVÁCS (det. Z. TOKÁR).

\section{C. flaviella MANN, 1857 [2618]}

The species has recently been found in Transylvania: Sânmarghita (jud. Mureş) and Cornești (jud. Cluj) by VICOL (in print).

\section{C. pattitella ZELLER, 1849 [2621]}

In Romania known from Oltenia: Gura Văii (jud. Mehedinți) (NEMEș 1968). 


\section{C. fuscociliella ZELLER, 1849 [2627]}

The species was recorded from Dobrogea only in the 19th century (MANN 1866). We collected further specimens in the Eastern Carpathians, Munții Perşani, Cheile Vârghisului, 700 m, 28.V.1982, 1 ㅇ, 23.V.1999, 1 o $^{\star}$, Munții Baraolt, 600 m, Atiușd, 5.VI.1982, 1 o , 2.VI.1996, 10 , legit: S. KOVÁCS \& Z. KOVÁCS (det. Z. TOKÁR).

\section{C. cracella VALLOT, 1835 [2635]}

Hitherto recorded only from Moldova (Grumăzeşti) by CARADJA (1901). We found it in Transylvania: Carpații Orientali, Munții Baraolt, 650 m, Sf. Gheorghe, 8.VII.1973, 1 \% , legit: S. KOVÁCS \& Z. KOVÁCS (det. Z. TOKÁR).

\section{C. kautzi REBEL, 1933 [2649]}

Mentioned from the Danube Delta (Letea) as C. andalusiae TOLL, 1960 by POPESCU-GORJ \&DRĂGHIA (1968).

\section{C. bilineella HERRICH-SCHÄFFER, 1855 [2653]}

The species was reported from Moldova: Slănic Moldova (CARADJA 1901).

\section{C. laricella (HÜBNER, 1817) [2683]}

Recorded from Moldova (CARADJA, cited by NEMEŞ 1968) and from the northwestern part of Romania, Turulung (jud. Satu Mare) (ARDELEAN 1998). We found it in the Eastern Carpathians, Munții Harghita, 700 m, Băile Jigodin, 9.VI.1998, 14 specimens, legit: S. KOVÁCS \& Z. KOVÁCS (det. Z. TOKÁR and Z. KOVÁCS)

\section{C. antennatiella HERRICH-SCHÄFFER, 1861 [2685]}

Only single old record is known from Transylvania, Sibiu (CZEKELIUS 1917).

\section{C. adjunctella HodgKInson, 1882 [2686]}

Recorded from Transylvania, Sibiu (CZEKELIUS 1917) and Dobrogea: Mamaia (NEMEŞ 1968).

\section{C. tamesis WATERS, 1929 [2688]}

This species was collected in Moldova, Suceava (NEMEŞ 1969), Zvoriştea (jud. Suceava) (NEMEŞ 1972) and in the Danube Delta (POPESCU-GORJ, OLARU \& DRĂGHIA 1972). 


\section{C. glaucicolella WoOD, 1892 [2689]}

The species was reported from several localities in Moldova, jud. Suceava (NEMES 1968, 1970a, NEMEŞ \& LUNGOCI 1972), Agapia (jud. Neamț) (NEMEŞ 1974) and in the Danube Delta (Caraorman) (POPESCU-GORJ \& DRĂGHIA 1974). Our data come from the Eastern Carpathians, Munți Harghita, Bicsad, 1-3.VII.1984, 10*; Munții Harghita, Hargitaliget, $700 \mathrm{~m}, 10$. VII.2001, $10^{*}$ and Şaru Dornei, Tinovul Mare, 18.VII.1991, $10^{*}$, legit: S. KOVÁCS \& Z. KOVÁCS (det. Z. TOKÁR).

\section{C. taeniipennella HERRICH-SCHÄFFER, 1855 [2693]}

The species was found in several Romanian localities in Moldova (Suceava), the southern Carpathians (Sinaia) (NEMEș 1968), the Danube Delta (POPESCU-GORJ \& DRĂGHIA 1974) and in Oltenia (Ieșelniţa, jud. Mehedinţi) (POPESCU-GORJ \& al. 1975).

\section{1assella STAUDINGER, 1859 [2697]}

C. lassella was mentioned several times from the Danube Delta NEMEŞ 1968, OLARU \&

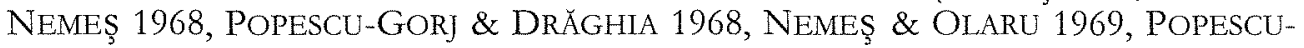
GORJ, OLARU \& DRĂGHIA 1972).

\section{C. halophilella ZIMMERMANN, 1926 [2708]}

Recorded from Dobrogea, Delta Dunării (POPESCU-GORj \& DRĂGHIA 1974), Transylvania, Ocna Sibiului (RAKOSY 1992) and Banat (NEUMANN 1998). We collected the species also in Transylvania: Carpații Orientali, Praid (jud. Harghita), Muntele de Sare, 18.VIII.2000, 10,1 ㅇ, legit: S. KOVÁCS \& Z. KOVÁCS (det. Z. TOKÁR)

\section{C. asteris MüHLIG, 1864 [2716]}

The species was recorded only from Transylvania: Sibiu (CZEKELIUS 1917).

C. sternipennella (ZETTERSTEDT, 1839) [2721]

C. sternipennella was listed in the Checklist of Romanian Microlepidoptera (POPESCUGORJ 1984). We found it in different parts of Transylvania: Carpații Orientali, Munţii Bodoc, Alungeni, 15-16.VIII.1985, $10^{\star}$; Toldal (jud. Mureş), 23.VII.1988, $10^{\star}$, legit: S. KOVÁCS \& Z. KOVÁCS (det. Z. TOKÁR).

\section{C. absinthii WOCKE, 1876 [2742]}

Known only from Moldova: Suceava (NEMEŞ 1968). 
C. occatella STAUDINGER, 1880 [2763]

In Romania recorded only from Dobrogea: Delta Dunării (POPESCU-GORJ, OLARU \& DRĂGHIA 1972).

\section{C. gnaphalii ZELLER, 1839 [2767]}

A single old record is known from Moldova: Grumăzești (jud. Neamț) (CARADJA 1901).

C. campestriphaga BALdizzone \& PATZAK, 1980 [2776]

VICOL (in litt.) recently found this species in Transylvania (Sânmarghita, jud. Mureş).

C. millefolii ZELLER, 1849 [2780]

A single record comes from Transylvania, Sibiu (CZEKELIUS 1922-1924).

C. peribenanderi Tour, 1943 [2786]

The species was reported from Moldova (Agapia, jud. Neamţ) by NEMEŞ (1974) and Oltenia (Ieşelniţa, jud. Mehedinţi) by POPESCU-GORJ \& al. (1975).

C. autumnella (DUPONCHEL, 1843) [2794]

(= asterifoliella KLIMESCH, 1939)

Only mentioned from Moldova: Pădurea Gârboavele (jud. Galați) (NEMEȘ 1968, NEMEŞ \& OLARU 1969).

\section{C. directella ZELLER, 1849 [2804]}

The species was recorded from Transylvania: Braşov (CZEKELIUs 1922-1924).

C. inulae Wocke, 1876 [2808]

C. inulae is hitherto known only from Dobrogea, Delta Dunării (POPESCU-Gorj \& DRĂGHIA 1968).

C. solitariella ZELLER, 1849 [2811]

Recently collected in Transylvania (Târgu Mureș, Budiu) (VICOL in litt.).

C. tanaceti MÜHLIG, 1865 [2812]

Hitherto the species was recorded only from Moldova, Suceava (NEMEȘ 1968). We found it in Dobrogea, Lespezi, 18.V.1994, 1 \%, legit: S. KOVÁCS \& Z. KOVÁCS (det. Z. TOKÁR). 
C. albicans ZELLER, 1849 [2816]

$(=$ artemisiella SCOTT, 1861)

Only reported from Dobrogea, Delta Dunării by POPESCU-GORJ \& al. (1972).

C. hackmani (TOLL, 1953) [2819]

The species was mentioned from Moldova: Pădurea Gârboavele (jud. Galați) (NEMEŞ 1968, NEMEŞ \& OLARU 1969).

C. argentula (STEPHENS, 1834) [2823]

The species was recorded from different Romanian regions: Dobrogea by MANN (1866), Transylvania (Vâlcele, jud. Covasna) by CZEKelius (1908), Moldova and Muntenia by NEMEŞ (1968). We found the species in the eastern Carpathians, Munții Baraolt, $650 \mathrm{~m}$, Sf.

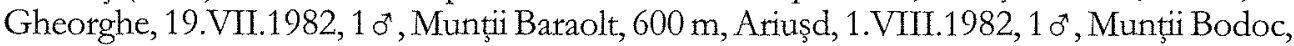
700 m, Valea Hereţ, 16.VII.1989, 1 \&, legit: S. KOVÁCS \& Z. KOVÁCS (det. Z. TOKÁR).

\section{C. peisoniella KASY, 1965 [2825]}

Recently discovered in saline habitats at Banat by NEUMANN (pers. com.).

\section{C. granulatella ZELLER, 1849 [2830]}

This species is known only from Dobrogea: Delta Dunării (OLARU \& NEMEŞ, 1968, NEMES 1968, NEMES \& OLARU 1969). Our specimen was found in the same district: Dobrogea, Grindul Chituc, Vadu, 28.VII.2000, 1 \% , legit: S. KovÁCS \& Z. KOVÁCS (det. Z. TOKÁR).

C. nutantella MÜHLIG \& FREY, 1857 [2845]

The species is hitherto known only from Transylvania: Şura Mică (jud. Sibiu) (CZEKELIUS 1908). We found it there, too: Carpaţii Orientali, Munții Harghita, Băile Jigodin, $650 \mathrm{~m}$, 30.V.2001, 1 ㅇ, legit: S. KOVÁCS \& Z. KOVÁCS (det. Z. TOKÁR \& G. BALDIZZONE).

C. graminicolella HEINEMANN, 1877 [2846]

Reported from Transylvania, Sibiu (CZEKELIUS 1922-1924).

C. preisseckeri ToLL, 1942 [2862]

C. preisseckeri was collected in Moldova: Pădurea Gârboavele (jud. Galaţi) (NEMEŞ \& OLARU 1969). 


\section{C. phlomidis STAINTON, 1867 [2867b]}

The first tecord of the species from Romania comes from Moldova, Iaşi, Valea lui David (NEMEş 1970b). We collected C. phlomidis in Dobrogea, Băneasa, Rezervația Canaraua Fetii, 12-13.VII.1993, 1 ơ, legit: S. KOVÁCS \& Z. KOVÁCS (det. G. BALDIZZONE).

\section{Remarks}

At first we have considered the following species as a new record for Romanian fauna. However, according recent investigation of the first author (BALDIZZONE 2002) C. balimionella is considered to be a new synonym of $C$. ocbroflava TOLL, 1961.

C. ochroflava ToLL, 1961 [2534]

(= balimionella BALDIZZONE, 1980 [2533])

Dobrogea, Valea Casimcei, Cheia, 29.VII.2000, 1 o (det. Z. TOKÁR)

Consequently C. ochroflava is now known from Italy, Greece, Bulgaria, Romania and Russia (BALDIZZONE 1996a, ANIKIN \& FALKOVITSH 1997).

The following three records from Romania probably belong to other coleophorids:

C. violacea (STRÖM, 1783) [2487]

Reported from Dobrogea (Hagieni) by POPESCU-GORJ \& DRĂGHIA (1967).

C. vulpecula ZELLER, 1849 [2581]

Recorded from Moldova by CARADJA (1901).

C. tricolor WALSINGHAM, 1899 [2657]

Recorded from Moldova (Ițcani, jud. Suceava) by NEMEș (1968).

\section{Acknowledgements}

We are grateful to Mr ANDRÁs KUN (Hungarian Natural History Museum, Budapest, Hungary), Mr Gabriel PAStorAlis (Komárno, Slovakia) and Dr PIERMaUro Giachino (Museo Regionale di Scienze Naturali, Torino) for delivery of the examined material. Our thanks are also extended to Mr JUKKA TABELL (Hartola, Finland) for the suggestion about the new synonymy, to Dr LÁszLÓ RÁKOSY (Cluj, Romania), Mr MARIN GoIA (Cluj, Romania), Prof VAsile VICOL (Târgu Mureș, Romania) and Mr HEINZ NEUMANN (Timişoara, Romania) for providing information about some Romanian Coleophoridae. Also a word of thanks to Dr HUGO W. VAN DER WOLF (Nuenen, The Netherlands), for help with the manuscript. 


\section{References}

ANIKIN, V. V. \& FALKOVITSH, M. I. 1997: On the casebearer fauna of the Lower Volga region (Lepidoptera: Coleophoridae). - Zoosystematica Rossica 5 (2) [1996]: 303-308.

Ardelean, G. 1998: Fauna judeţului Satu Mare, Ţara Oaşului, Culmea Codrului şi Câmpia Someşului. „Vasile Goldiş“ Univ. Press: 155-218.

BALDIZzone, G. 1980: Contribuzioni alla conoscenza dei Coleophoridae, XXIII. Coleophora balimionella n. sp. - Entomologica, Bari 16: 31-40.

BALDIZZONE, G. 1981: Contribuzioni alla conoscenza dei Coleophoridae. XXIV. Le specie descritte da W. KRONE, J. MANn, K. ProHASKA, H. Zerny. - Folia Entomologica Hungarica, Budapest 42 (1): 5-12.

BALDIZZONE, G. 1983: Records of the Lepidoptera of Greece based on the collections of G. CHRISTENSEN and L. GOZMÁNY: III, Coleophoridae. - Annales Musei Goulandris, Kifissia 6: 207-248.

BALdizzONE, G. 1986: Contributions à la connaissance des Coleophoridae. XLII. Sur quelques Coleophoridae d'Espagne (Seconde partie: Espèces nouvelles pour la Faune espagnole, ou peu connues). - Nota lepidopterologica, Basel 9 (1-2): 2-34.

BALDIZZONE, G. 1994: Contribuzioni alla conoscenza dei Coleophoridae. LXXV. Coleophoridae dell' Area IranoAnatolica e regioni limitrofe (Lepidoptera). - Associazione Naturalistica Piemontese, Memorie 3: 1-424, 699 figs.

BALDIZZONE, G. 1996a: Coleophoridae. - In: KARSHOLT, O. \& RAZOwSKI, J. (eds.): The Lepidoptera of Europe. - Apollo Books, Stenstrup, 380 pp.

BALDIzZONE, G. 1996b: I microlepidotteri del Parco Naturale del Mont Avic e zone limitrofe (Valle d'Aosta - Val Chalamy - Alpi Graie orientali). - Revue Valdôtaine d'Histoire Naturelle 50: 55-141.

BALDizzone, G. 1997: Contribuzioni alla conoscenza dei Coleophoridae. LXXXVII. Coleophoridae nuovi o poco conosciuti dell' Africa settentrionale (Lepidoptera: Coleophoridae), - SHILAP Revista de Lepidopterologica, Madrid 25 (100): 219-257.

BAtDIZZONE, G. 2000: Contribuzioni alla conoscenza dei Coleophoridae. XCII. Coleophoridae nuovi o poco conosciuti delle Alpi Cozie (Lepidoptera). - Rivista Piemontese di Storia Naturale 21: 277-298.

BALDIZZONE, G. 2002: Contribuzioni alla conoscenza dei Coleophoridae. XCIX. Nuove sinonimie nel genere Coleophora HüBNER (VIII) (Lepidoptera). - Bollettino del Museo regionale di Scienze naturali, Torino 19 (1): 115-120.

BAldizzone, G. \& Hartig, F. 1978: Die Sardischen Coleophoriden in den Sammlungen von G. BALdizZONE, F. HARTIG und L. GOZMÁNY (Lepidoptera: Coleophoridae). - Folia Entomologica Hungarica, Budapest 31 (2): 25-51.

BALDIZZONE, G. \& TRIBERTI, P. 1982: Note su alcuni interessanti microlepidotteri raccolti in Puglia. Entomologica, Bari 17: 41-46.

BALDIZZONE, G. \& WOLF VAN DER, H. W. 2000: Corrections and additions to the Checklist of European Coleophoridae (Lepidoptera: Coleophoridae). - SHILAP Revista de Lepidopterologia, Madrid 28 (112): 395-428.

CĂPuSE, I. \& KovÁCS, A. 1987: Catalogue de la collection de lépidoptères „László Diószeghy” du Muzée dápartamental Covasna, Sfîntu Gheorghe. - Institut de Spéologie "Émile Racovitza", Bucarest.

CARADJA, A. 1901: Die Microlepidopteren Rumäniens. - Buletinul Societăţi de Sciințe, Bucarest 10 (1-2): 110-168.

CZEKELIUS, D. 1908: Beiträge zur Schmetterlingsfauna Siebenbürgens. - Verhandlungen und Mittheilungen des siebenbürgischen Vereins für Naturwissenschaften zu Hermannstadt, Hermannstadt 58: 153-164.

CZEKELIUS, D. 1917: Beiträge zur Schmetterlingsfauna Siebenbürgens. - Verhandlungen und Mittheilungen des siebenbürgischen Vereins für Naturwissenschaften zu Hermannstadt, Hermannstadt 67 (1-6): 1-56.

CZEKELIUS, D. 1922-1924: Beiträge zur Schmetterlingsfauna Siebenbürgens. - Verhandlungen und Mittheilungen des siebenbürgischen Vereins für Naturwissenschaften zu Hermannstadt, Hermannstadt 72-74: 1-10.

CZEKELIUS, D. 1933-1934: Beiträge zur Schmetterlingsfauna Siebenbürgens. - Verhandlungen und Mittheilungen des siebenbürgischen Vereins für Naturwissenschaften zu Hermannstadt, Hermannstadt 83-84: 59-69. 
DobreANU, E. 1937: Contribuțiuni la studiul sistematic morfologic şi biologic al insectelor miniere din România. - Facultea de Ştiinţ̧e Laboratorul Zoologic București, 128 pp.

Falkovitsh, M. I. 1988: K faune chehlonosok (Lepidoptera, Coleophoridae) juzhnoj Turkmenii (s opisaniem novyh vidov). Chast 1. - Trudy Zoologitscheskogo Instituta Academii Nauk SSSR, Leningrad 178: 134-162.

FALKOVITSH, M. I.; JALAVA, J. \& MiKKOLA, K. 1997: Records of casebearers from Siberia, Russia (Coleophotidae). - Nota lepidopterologica 20 (3/4): 310-321.

GAEDIKE, R. \& HEINICKE, W. (eds.) 1999: Verzeichnis der Schmetterlinge Deutschlands (Entomofauna Germanica 3). - Entomologische Nachrichten und Berichte (Dresden), Beiheft 5: 1-216.

GLASER, W. 1975: Beittag zur Kenntnis der Coleophoridae, VII. Eine neue Coleophorenart aus Südspanien.

Erste Stände und das Männchen von Col. nitidipenzella TOLL \& AMSEL, 1967. Das Männchen von Col. coarctataephaga TOLL, 1961 (Lepidoptera, Coleophoridae). - Zeitschrift der Arbeitsgemeinschaft Österreichischer Entomologen, Entomologisches Nachrichtenblatt 27 (1/2): 19-24, 10 frgs.

GREGOR, F.; LAŠTƯVKA, A., LAŠTƯVKA, Z. \& MAREK, J. 1984: Zur Verbreitung der Coleophora-Arten in der Tschechoslowakei (Lepidoptera, Coleophoridae). - Biológia, Bratislava 39 (10): 1023-1032.

GREGOR, F, LAŠTUVVKA, A., LAšstưvKA, Z. \& MAREK, J. 1986: Doplňky k faunistice druhů rodu Coleophora v Ceskoslovensku [Beitrag zur Faunistik der Coleophora-Arten in der Tschechoslowakei] (Lepidoptera, Coleophoridae). - Zprávy Československé společnosti entomologické pri ČSAV 22: 33-46.

HeRING, E. M. 1957: Bestimmungstabellen der Blattminen von Europa. W. Junk, Gravenhage, 1185 pp + 86 Taf.

HORMUZAKI, C. 1907: Die Schmetterlinge (Lepidoptera) der Bukowina (III). Fam. Pyralidae bis Micropterigidae. - Verhandlungen der zoologisch-botanischen Gesellschaft in Wien, Wien 57: 34-104.

HRUBY, K. 1964: Prodromus Lepidopter Slovenska. Prodromus Lepidopterorum Slovaciae. - SAV, Bratislava, $962 \mathrm{pp}$.

ITÄMIES, J.; KYRKI, J. \& VIRAMO, J. 1979: Die Biologie der Coleophora plumbella (Lepidoptera, Coleophoridae). - Notulae Entomologicae. - Helsingfors 59: 165-167.

ITÄMIES, J. \& TABEll, J. 1991: Coleopbora idaeella HOFMANN, 1869 ja C. vaciniella HERriCH-SCHÄFfer, 1861 (Lepidoptera, Coleophoridae): uusia ravintokasvi- ja elintapahavaintoja. - Baptria 16 (2): 47-50.

IVINSKIS, P. \& SAVENKKOV, N. 1991: Casebearers of the Baltic republics (Lepidoptera: Coleophoridae). Phegea 19 (4): 149-167.

KASY, F. 1979: Die Schmetterlingsfauna des Naturschutzgebietes Hackelsberg, Nordburgenland. - Zeitschrift der Arbeitsgemeinschaft Österreichischer Entomologen, Entomologisches Nachrichtenblatt 30 (Supplement): $1-44$.

KASY, F. 1985: Die Schmetterlingsfauna des Naturschutzgebietes "Pischelsdotfer Fischawiesen", östliches Niederösterreich. - Zeitschrift der Arbeitsgemeinschaft Österreichischer Entomologen, Entomologisches Nachrichtenblatt 36 (Supplement): 1-27, 8 text-figs.

KIIMESCH, J. 1939: Die Raupe der Coleopbora rectilineella F.R. (Lep., Coleophoridae). - Zeitschtift des Österreichischen Entomologen-Vereins, Wien 24: 39-43, 13 figs.

KLIMESCH, J. 1968: Die Lepidopterenfauna Mazedoniens, IV. Microlepidoptera. - Prirodonaucen Muzej na Makedonija, Skopje 5: 1-201.

KLIMESCH, J. 1990: In: KUSDAS, K. \& REICHL, E. R.: Die Schmetterlinge Oberösterreichs, Teil 6: Microlepidoptera (Kleinschmetterlinge) I. - Linz, $332 \mathrm{pp}$.

KOÇAK, A. \& SEVEN, S. 2001: Tentative Checklist of the Turkish Lepidoptera. www.members,tripod.com/ entlep/checklist 1 .htm

KÖNIG, F. 1975: Catalogul colecției de lepidoptere a Muzeului Banatului. Timişoara, 284 pp.

MANN, J. 1866: Aufzählung der im Jahre 1865 in der Dobrudscha gesammelten Schmetterlinge. Verhandlungen der zoologisch-botanischen Gesellschaft in Wien, Wien 16: 1-40.

MAREK, J. \& GREGOR, F. 1989: Faunistic records from Czechoslovakia. Lepidoptera. - Acta Entomologica Bohemoslovaca 86: 157.

NEMEŞ, I, 1968: Familia Coleophoridae lor în R.S.R. (Lepidoptera). - Societatea de Științe, Biologie, Comunicări Zoologice 8: 131-146. 
NEMEŞ, I. 1969: Coleophoridae noi în fauna R.S.R. (Lepidoptera). - Societatea de Ştiințe, Biologie, Comunicări Zoologice, Ptima Consfătuire Naţională de Entomologie, București: 129-134.

NEMEŞ, I. 1970a: Considerațini sistematice, zoogeografice si ecologice asupra faunei lepidopterelor din rezervaţile ştiinţifice de la Frumoasa şi Ponoare, județul Suceava (I). - Lucrările sesiunii ştiinţifice pentru ocrotirea naturii în județul Suceava: 115-138.

NEMES, I. 1970b: Coleophora phlonididis STT, în Republica Socialistă România (Lepidoptera), - Muzeul Județcan Suceava. Studii şi Comunicări, Științele Naturii: 69-72.

NEMEş, I. 1972: Fauna de lepidoptere a judeţului Botoşani. Part. I. - Studii și Comunicări, Muzeul de Ştiinţe Naturale Dorohoi: 179-186.

NemEș, I. 1974: Contribuții la cunoașterea lepidopterelor din județul Neamţ. (Partea I: Agapia). - Muzeul de Ştiințe Naturale Piatra Neamţ. Studii şi Cercetări Geologie-Geografie-Biologie, secțiunea de BotanicăZoologie: 203-216.

NEMEŞ, I. \& DĂNILA, I. 1970: Catalogul colecției de lepidoptere "Alexei Alexinschi" de la Muzeul Județean Suceava. Partea I-a. - Muzeul Judetean Suceava. Stud. Com. Şt. Nat.: 131-265.

NEMEŞ, I. \& LUNGOCI, A. 1972: Fauna de lepidoptere din rezervația naturală Tinovul Mare (Poiana Stampei) jud. Suceava. - Studii şi Comunicări, Ocrotirea Naturii Suceava: 269-278.

NEMEŞ, I. \& OLARU, V. 1969: Contribuție la cunoaşterea Coleophoridaelor din sudul şi sud-estul României (Lepidoptera). - Lucrările Ştiințifice ale Instutului Pedagogic Galaţi 3: 119-125.

Neumann, H. 1998: Fauna de lepidoptere a zonelor sărăturoase din Câmpia Banatului. - Analele Banatului 4: $185-212$.

OLARU, V. \& NEMEŞ, I. 1968: Contributii la studiul lepidopterelor din pădurea Gârboartele (II). - Lucr. Şt. Inst. Pedag. Galați 2: 167-177.

OLARU, V. \& NEMEș, I. 1970: Contribuții la cunoaşterea lepidopterelor din pădurea Gârboavele (IV). Lucr. Șt. Inst. Pedag. Galați 4: 125-134.

PATZAK, H. 1974: Beiträge zur Insektenfauna der DDR: Lepidoptera - Coleophoridae. - Beiträge zur Entomologie, Berlin 24 (5/8): 152-278.

POPESCU-GORJ, A. 1984: La liste systématique des espèces de Microlépidoptères signalées dans la faune de Roumanie, mise á jour de leur classification et nomenclature. - Travaux du Muséum d'Histoire Naturelle "Grigore Antipa", Bucarest 26: 111-162.

POPESCU-GORJ, A. 1995: Lepidopterans from the surroundings of the Town Sinaia and from Bucegi Mountains (Romania). - Travaux du Muséum d'Histoire Naturelle "Grigore Antipa", Bucarest 35: 161-220.

POPESCU-GORJ, A. \& DRĂGHIA, I. 1967: Ord. Lepidoptera. In: L'Entomofaune des forêts du sud de Dobroudja. - Travaux du Muséum d'Histoire Naturelle "Grigore Antipa", Bucarest 7: 181-212.

POPESCU-GORJ, A. \& DRĂGHIA, I. 1968: Ord. Lepidoptera. In: POPESCU-GORJ, A. \& SCOBIOLA-PALADE, X.: L'entomofaune de l'île de Letea (Delta du Danube). - Travaux du Muséum d'Histoire Naturelle "Grigore Antipa", Bucarest 9: 227-278.

POPESCU-GORJ, A. \& DRĂGHIA, I. 1974: Ord. Lepidoptera. In: L'entomofaune du "grind" Sărăturile Sf. Gheorghe (Delta du Danube). - Travaux du Muséum d'Histoire Naturelle "Grigore Antipa", Bucarest 14: $157-163$.

POPESCU-GORJ, A.; OlARU, V. \& DRAGHIA, I. 1972: Ord. Lepidoptera. In: L'Entomofaune du "grind" de Caraorman (Delta du Danube). - Travaux du Muséum d'Histoire Naturelle "Grigore Antipa", Bucarest 12: 181-206.

Popescu-GorJ, A.; KÖnig, F; PeIU, M.; Niculescu, E. V.; lonescu, M. \& Drăghia, I. 1975: Lepidoptera. In: Grupul de cercetări complexe "Porțile de Fier". Fauna: 214-255.

RÁKOSY, L. 1992: Bioökologische und zoogeographische Studien der Noctuiden (Lepidoptera, Noctuidae) in der Region der Salzbäder von Ocna Sibiului (Siebenbürgen, Rumänien). - Nota lepidopterologica 3 (Supplementa): 46-57.

Razowski, J. 1990: Motyle (Lepidoptera) Polski. Cześć 16 - Coleophoridae, PWN Warszawa, 272 pp. 
ReIprich, A. 2001: Triedenie motýlov Slovenska podla hostitelov (živných rastlín) ich húseníc [Die Klassifikation der Schmetterlinge der Slowakei laut den Wirten (Nährpflanzen) ihrer Raupen]. - Správa Národného parku Slovenský raj, Spišská Nová Ves, 480 pp.

REBEL, H. 1911: Die Lepidopterenfauna von Herkulesbad und Orsova. Eine zoogeographische Studie. Annales Naturhistorisches Hofmuseum Wien 25: 17-430.

RothsCHIL, CH. 1912: Beitrag zur Lepidopterenfauna der Mezöség. - Verhandlungen und Mittheilungen des siebenbürgischen Vereins für Naturwissenschaften zu Hermannstadt, Hermannstadt 62 (1): 1-32.

SCHÜTZE, K. T. 1931: Die Biologie der Kleinschmetterlinge unter besonderer Berücksichtigung ihrer Nährpflanzen und Erscheinungszeiten. - Frankfurt am Main, 235 pp.

Szöcs, J. 1977: Lepidoptera - aknák és - gubacsok - Hyponomia et Cecidia Lepidopterorum. - Fauna Hungariae, 16. Lepidoptera. Akadémiai kiadó, Budapest, 424 pp.

SVENSSON, I. 1993: Fjärilkalender. Lepidoptera-calendar. Kristianstad, 124 pp.

TOLL, S. 1953: Rodzina Eupistidae Polski. - Materialy do fizjografii Kraju 32: 1-292, 38 tab.

TOLL, S. 1961: Zoologische Ergebnisse der Mazedonienreisen FRIEDRICH KASY, I Teil Lepidoptera Coleophoridae. - Sitzungsberichte der Österreichischen Akademie der Wissenschaften, Mathematischnaturwissenschaftlichen Klasse, I. Abteilung 170 (7/10): 279-303, 54 figs.

TOLL, S. 1962: Materialien zur Kenntnis der paläarktischen Arten der Familie Coleophoridae (Lepidoptera). - Acta zoologica Cracoviensia, Kraków 7 (16): 577-718.

VICOL, V. (in print): Coleophora flaviella MANN, 1857 (Lepidoptera, Coleophoridae) specie nouă pentru fauna României. - Buletinul de informare Societatea lepidopterologică română.

VICOL, V. (in litt.): Contributions à la connaissance des Coleophoridae dans la fauna de Microlépidoptères de Roumanie. - Travaux du Muséum d'Histoire Naturelle "Grigore Antipa", Bucarest.

VILLEGAS, B. \& HARRIS, P. 2002: Coleopbora klimeschiella - "Russian Thistle Casebearer".www.wes.army.mil/ el/emrrp/emris/emrishelp3/coleophora_klimeschiella.htm

VIVes Moreno, A. 1988: Catalogo mundial sistematico y de distribucion de la familia Coleophoridae HÜBNER, [1825] (Insecta: Lepidoptera). - Ministerio de Agricultura, Pesca y Alimentación, Madrid, 196 pp.

WOLF, H. W. VAN DER, 2001: Coleophora taygeti BALDIZZONE, 1983, espèce nouvelle pour la France (Lepidoptera Coleophoridae). - Alexanor 21 (4), 1999 (2001): 239-240.

\section{Author's addresses:}

Dr. GIORGIO BALDIZZONE

Via Manzoni, 24

I-14100 Asti

Italy

E-mail: giorgiobaldizzone@tin.it

ING ZDENKO TOKÁR

Hollého 78/10

SK-071 01 Michalovce

Slovak Republic

E-mail: ztokar@post.sk

\author{
ZOLTAN KOVÁCS \\ str. Timisoarei nt. 31/6 \\ RO-4100 Miercurea-Ciuc \\ Romania \\ E-mail:kovacs@nextra.ro
}

\author{
SÁNDOR KOVÁCS \\ str. Oltului nt. 57. bl. 6/A/6 \\ RO 4000 Sfintu-Gheorghe \\ Romania \\ E-mail: kovacs@,cosys.ro
}

